\title{
Academia Brasileira de Ciências Políticas e Administrativas de Brasília (*)
}

\author{
Braz de Sousa Arruda \\ Catedrático de Direito Internacional Páblico \\ na Universidade de São Paulo.
}

No momento da fixação definitiva dos quadros institucionais, jurídicos e administrativos, da futura Capital brasileira, julgo ser de meu dever, como cidadão consciente da extraordinária imṕortância de Brasília no processo de desenvolvimento econômico e social da nação, formular um respeitoso apêlo a Vossa Excelência para que determine as providências conducentes ao estudo e à implantação - no âmbito das instituições fundamentais e complementares reclamadas pela mudança da Capital — de uma Academia de Ciências Políticas e Administrativas, capaz de constituir-se em centro universitário de análise, de cursos e de pesquisas, destinado a estudar, sob ângulo preponderantemente administrativo, os principais problemas do país.

Essa instituição científica supriria lacuna sensível no aparelhamento universitário brasileiro. Podendo valer-se da oportunidade excepcional da conservação dos Ministérios e das unidades autônomas governamentais no mesmo centro orgânico de pioneirismo e de equilíbrio do nosso arcabouço político, estaria apta, por outro lado, a adquirir sensibilidade para auscultar, numa perspectiva unitária e renovadora, as questôes fundamentais do país no setor das

(*) Carta do Professor Braz de Sousa Arruda ao Senhor Presidente da República, Dr. Juscelino Kubitschek. 
peculiaridades a que se propõe servir. Tal como a Escola Nacional de Administração da França, deveria colaborar no aperfeiçoamento dos quadros superiores da administração e situar-se, ao mesmo tempo, como organismo subordinado diretamente ao escalão superior do Govêrno da República.

Professor e Decano da Faculdade de Direito da Universidade de São Paulo, de que fui Diretor durante seis anos, antigo Presidente do Instituto Hispano-Luso-Americano de Direito Internacional, de cujo Conselho Diretor participo, membro que fui do Conselho Administrativo do Estado de São Paulo, enfim, tôda a minha não limitada experiência no âmbito administrativo e universitário me induz, demais, a asseverar a extrema conveniência de se conferir a essa Academia - precisamente pelas características especiais que a definem - uma estrutura que a distinga das demais entidades universitárias brasileiras. Importa conferir-lhe extrema flexibilidade bem como propiciar-lhe a valiosa colaboração de especialistas de diferentes centros do país e do estrangeiro, nos moldes aliás do que ocorre na Academia de Direito Internacional de Haia, na Escola de Funcionários Internacionais de Madrid, na Academia de Saragoça, a cujos quadros os professôres não se integram, via de regra, de forma burocrática e permanente.

Obra de tão elevados propósitos e singularmente oportuna em face da conjuntura política e social que atravessamos, são manifestas suas consequências salutares no aperfeicoamento educacional e administrativo de nossa gente. Reclama ela, é certo, o concurso patriótico e o idealismo realizador de todos quantos desejam trabalhar ativamente em prol do desenvolvimento de nossas instituiçôes.

Não posso destarte furtar-me, por outro lado, ao dever de colocar-me à disposição de Vossa Excelência para colaborar, na medida de minhas fôrças, e no que puder ser útil, à tarefa ingente e gloriosa de planejamento e organi- 
zação, na futura Capital brasileira, de uma Academia Política e Administrativa, em bases rigorosamente científicas, e como forma de cooperar, de maneira objetiva, na construção da Cidade nova, marco de consagração do Govêrno e da personalidade dinâmica de Vossa Excelência.

Valendo-me desta honrosa oportunidade, apresento a Vossa Excelência, Senhor Presidente da República, protestos de profundo apreço e constante admiração. 